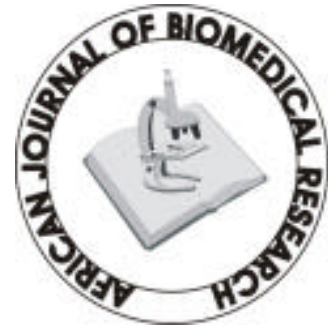

Full-text available at http://www.ajbrui.com \&

http://www.bioline.br/md

Received:

June, 2005

Accepted (Revised):

November, 2005

Published

January, 2006
Full Length Research Article

\section{Seasonal Variations in antibody response to a Plasmodium falciparum recombinant circumsporozoite antigen in two villages in South Western Nigeria}

\author{
${ }^{1}$ Ozurumba, L.N; ${ }^{1}$ Anumudu, C.I.; ${ }^{* 1}$ Nwagwu, M.N. \\ ${ }^{1}$ Cellular Parasitology Programme, \\ Department of Zoology, \\ University of Ibadan, Nigeria
}

\section{ABSTRACT}

An Enzyme Linked Immunosorbent Assay (ELISA), employing a recombinant peptide capture antigen (R32tet32) was used to detect antibodies against the circumsporozoite protein (CSP) of the malaria parasite, Plasmodium falciparum in 169 serum samples from 16 subjects from two villages, Afefu (FA) and Tobalogbo (TB), in Igbo-Ora Community of Oyo State, over a period of 12 months. The maximum and mean $A b$ response for $F A$ was higher than for TB samples $(0.511$ $A U \pm 0.170, \quad 0.124 \pm 0.045 U$ and $0.250 \pm 0.070 A U, 0.090 \pm 0.019 A U$ respectively), with the mean $A b$ being significantly different ( $t=2.313$; $P>0.05$ ). Despite both villages (FA and TB) falling within the same rainfall data zone, the $A b$ response profile for $F A$ showed a positive (seasonal) relationship with rainfall $(r=+0.31, P>0.05)$ while that of $T B$ was negatively correlated $(r=-0.32 ; P>0.05)$. Habits and the environment could be prime contributing factors alongside the less controllable immunogenetic factors. Data obtained here would serve as baseline and we suggest other expanded sample size studies to include data on temperature and other climatic factors to help establish sub-populations at risk and better empower malariologists in planning and execution of control programmes (Afr. J. Biomed. Res. 9: 37 - 43, 2006)

Keywords: Antibodies, Enzyme Linked Immunosorbent Assay (ELISA),

Circumsporozoite Protein, Antigen

*Author for Correspondence: 02-8101430; Fax (02) 8103118, 8103043; emailnwagwu@skannet.com

Abstracted by:

African Index Medicus (WHO), CAB Abstracts, Global Health Abstracts, Asian Science Index, Index Veterinarius 


\section{INTRODUCTION}

Parasites of the genus Plasmodium places a huge burden on human life as a result of the malaria disease they cause. It remains a threat to almost $50 \%$ of the world's population with 200 million estimated new cases and 1-2 million deaths per year (Snow et. al., 1998). Individuals in all continents are potentially at risk, but the greatest deficiency falls on people in the tropics.

Malaria is initiated with the inoculation of sporozoites from infected female anopheles mosquitoes. These sporozoites have a short life span and are highly immunogenic (Tapcharsri et al., 1983; Nussenzweig et al., 1985). CSP is a major surface antigen which uniformly surrounds the external coat of the malaria sporozoite (Cochrane et al, 1980; the circumsporozoite tetrapeptide present their-in was derived from an open reading frame in the tetracydine resistant region (TCR) of E.coli expression plasmid (Webster et al.., 1987).

Elaborate seroepidemiological studies have been made possible by ELISAs. They help in the definining and collaboration of baseline data on the development of natural immunity to malaria in remote locations. Thus helping in monitoring progress made in malaria control programmers (Tapchaisri et al, 1985). The seasonality of malaria has been recorded by the likes of Webster et al (1988) and Babiker et. al., (1998). In a study, Lindsay and Birley (1996) stated that the transmission of P.falciparum depends upon the survival, abundance and infectious periods of the malaria while the vector rely upon suitable climatic conditions. Snow et al.(1998) on the other a hand showed in their work that areas with low rainfall limits the transmission potential while the areas with low temperature reduce the duration of both the sporogonic and gonotrophic cycles; thus limiting the chances of parasite transmission. Classical works by Esposito et al (1988) and Druilhe et al (1986) indicated a substantial seasonal variation in the levels of antibodies to the synthetic recombinant antigens, even in adults living in areas of extreme high malaria transmission.

Climate-based models are being developed to identify and monitor geographical areas that are most at risk from malaria epidemics. The models predict risk of malaria transmission on the basis of rainfall and temperature and validation of the results generated from the model using historical malaria data, have shown that such models provide a good estimation of spatial risk (WHO/TDR, 2004). Of global deaths attributed to malaria, 90\% now occur in sub-saharan Africa. Recent advances in public health are offering new opportunities to make significant reductions in burden of disease (MARA/ARMA, 2001); and malaria risk mapping, offers such a service which can help to better support planning and programming of malaria control. Though seasonality of malaria transmission pattern has been reported in previous studies, as highlighted above, in this paper, we attempt opening up the variability in patterns of falciparum malaria $\mathrm{Ab}$ responses and the potential positive complimentary, role of malaria risk mapping in control.

The objectives of this paper include the determination of the individual and mean levels of $\mathrm{Ab}$ response to the CSP (R32tet32) construct. Also, the relationship of Ab response to rainfall in each of the villages were compared. The work will also bring to light, the role of ELISA and potential role of spatial risk mapping in the control of malaria.

\section{MATERIALS AND METHOD}

Study site: The two villages Afefu and Tobalogbo are located in Igbo-Ora community in the Ifeloju Local Government areas of Oyo State.

Subjects: They were participants in a longitudinal epidemiological study carried out by the Cellular Parasitology Programme research team. 169 serum samples including 2 controls were used for the study. Samples were collected fortnightly.

Approximately 500ul of blood was obtained by finger pricking from each subject and transferred into anticoagulant containing micro-test tubes. The blood samples were transported to Ibadan on ice packs. These were later brought into the laboratory after 2-6 hours and stored at $4^{\circ} \mathrm{C}$ for $24-48$ hours. The samples were centrifuged at $10,000 \mathrm{rpm}$ for 5 minutes at $4^{\circ} \mathrm{C}$. The sera subsequently obtained were stored in small aliquots at $-70^{\circ} \mathrm{C}$ in the laboratory. They were hter stored at $4^{0} \mathrm{C}$, enable the samples to thaw before running assays on them.

Cahorts were discouraged from taking anti-malarial agents such as "Agbo" prepared from the neem tree, Azadirachta indica before entering the survey. They were supplied with drugs and treated for various ailments at the Centre for Preventive and Social Medicine of the Ibadan University College Hospital (UCH) in Igbo-Ora. Subjects were indigenes of the community. They live in the farm during the weekdays and move to town at weekends.

ELISA method: A total of 169 serum samples were tested by an enzyme-linked immunosorbent assay (ELISA) using R32tet32 as capture antigen in 8 microtitre plates. On the first day, the stock capture antigen was diluted at a concentration of 1:2,000 with solution A (Boiled casein and phosphate buffered saline at a dilution of 4:5,000) 50ul was evenly dispensed into each of the wells (nos. 2-11) of the 8 microtitre plates using multichannel pipettor. These plates were covered and incubated overnight at $4{ }^{\circ} \mathrm{C}$. This was followed by aspiration of well contents using a multichannel pipettor. Each of the wells were then filled with $200 \mathrm{ml}$ blocking buffer and left for 1hour at laboratory temperature. The 169 test human sera samples were 
diluted 1:200 in blocking buffer in small tubes including the control positive and negative sera. Then, $50 \mathrm{ul}$ of this solution was dispensed in duplicates (to ensure follow-up re-runs, for reproducibility) into each of the wells 3 to 11 and the plates covered. After a-2 hour incubation at room temperature, the well contents were aspirated, the plates washed twice with $0.5 \%(\mathrm{v} / \mathrm{v})$ PBS-Tween 20 wash solution. The $1^{\text {st }}$ and $12^{\text {th }}$ rows, and the peripheral wells had no sera samples (blanks). The plates were then blotted and 50ul of peroxidase conjugated mouse antihuman immunoglobin $\mathrm{G}$ (IgG) solution diluted 1:5000 in blocking buffer was added to each well. The plates were allowed to stand at laboratory temperature for 1 hour, the plates were aspirated and washed twice with the PBSTween 20 wash solution. 50ul of ABTS substrate was added to each well covered and incubated in the dark for 1 hour. Then, $50 u$ of $1 \%$ SDS solution was added into each well to stop the reaction. The absorbance values at wavelenth of 405nmwas determined using a Vmax kinetic microplate reader (Responders: mean ELISA absorbance value $>0.09 \mathrm{AU}$ ). The absorbance values of the blanks for each column were subtracted from the absorbance values for the wells containing R32tet32. The mean values and the standard deviation (SD) was then calculated. The format used permitted sera from 2 subjects to be assayed per plate for the 13 months duration. Samples were not obtained for few of the months for some subjects. Hence the base line insight of the data. The positive control sera came from an individual who was shown to be making anti-circumsporozoite antibodies while the negative control sera came from an individual who was not shown to be making anti-circumsporozoite antibodies in a longitudinal study on natural immunity to malaria in a falciparum malaria endemic area (Igbo-Ora).

Statistical analysis was done using mean values, SD, student ' $t$ ' test and the person product moment correlation coefficient.

\section{RESULTS}

The maximum mean absorbance values were obtained in the months of August $(0.202 \pm 0.160 \mathrm{AU})$ for FA samples and in the months of April, $1993(0.143 \pm 0.084 \mathrm{AU})$ for TB samples. (Tables $1 \& 2$ ). Table shows the monthly mean absorbance values of FA samples.

Table 1: The monthly mean absorbance values of FA samples (mean monthly rainfall data included)

\begin{tabular}{|c|c|c|c|c|c|c|c|c|c|c|}
\hline MTH & Rainfall * & FA 02 & FA 05 & FA 07 & FA 012 & FA 14 & FA28 & FA29 & FA31 & Mean \\
\hline April 1 & 150 & $\begin{array}{c}0.165 \pm \\
0.0269\end{array}$ & $\begin{array}{c}0.1445 \pm \\
0.0275\end{array}$ & $\begin{array}{c}0.046 \pm \\
0.0057 \\
\end{array}$ & $\begin{array}{c}0.1930 \pm \\
0.0410\end{array}$ & $\begin{array}{c}0.1625 \pm \\
0.0361 \\
\end{array}$ & - & - & - & 0.142 \\
\hline May & 155 & $\begin{array}{c}0.0515 \pm \\
0.0064\end{array}$ & - & $\begin{array}{c}0.044 \pm \\
0.0055 \\
\end{array}$ & - & - & $\begin{array}{c}0.0395 \pm \\
0.0347\end{array}$ & - & - & 0.045 \\
\hline June & 210 & $\begin{array}{c}0.3375 \pm \\
0.2112 \\
\end{array}$ & - & - & $\begin{array}{c}0.2110 \pm \\
0.0085\end{array}$ & $\begin{array}{c}0.0070 \pm \\
0.0141 \\
\end{array}$ & $\begin{array}{c}0.0545 \pm \\
0.0007\end{array}$ & $\begin{array}{c}0.0515 \pm \\
0.0177\end{array}$ & $\begin{array}{c}0.0860 \pm \\
0.0170\end{array}$ & 0.135 \\
\hline July & 175 & $\begin{array}{c}0.3815 \pm \\
0.1096\end{array}$ & $\begin{array}{c}0.0775 \pm \\
0.0191\end{array}$ & $\begin{array}{c}0.0230 \pm \\
0.0127\end{array}$ & $\begin{array}{c}0.5105 \pm \\
0.1732 \\
\end{array}$ & $\begin{array}{c}0.1190 \pm \\
0.0042\end{array}$ & $\begin{array}{c}0.1790 \pm \\
0.0057\end{array}$ & $\begin{array}{c}0.0345 \pm \\
0.0021\end{array}$ & $\begin{array}{c}0.0095 \pm \\
0.0035\end{array}$ & 0.167 \\
\hline Aug & 125 & $\begin{array}{c}0.4425 \pm \\
0.1153\end{array}$ & - & $\begin{array}{c}0.0530 \pm \\
0.0339\end{array}$ & $\begin{array}{c}0.2750 \pm \\
0.0424\end{array}$ & $\begin{array}{c}0.1580 \pm \\
0.0255\end{array}$ & $\begin{array}{c}0.0825 \pm \\
0.0078\end{array}$ & - & - & 0.202 \\
\hline Sept & 175 & - & $\begin{array}{c}0.0850 \pm \\
0.0255\end{array}$ & $\begin{array}{c}0.0070 \pm \\
0.0028\end{array}$ & $\begin{array}{c}0.2060 \pm \\
0.0226\end{array}$ & - & $\begin{array}{c}0.2460 \pm \\
0.0028 \\
\end{array}$ & $\begin{array}{c}0.0265 \pm \\
0.0106\end{array}$ & $\begin{array}{c}0.0040 \pm \\
0.0014\end{array}$ & 0.096 \\
\hline Oct & 180 & $\begin{array}{c}0.3735 \pm \\
0.0050 \\
\end{array}$ & $\begin{array}{c}0.0675 \pm \\
0.0035 \\
\end{array}$ & $\begin{array}{c}0.0320 \pm \\
0.0028 \\
\end{array}$ & $\begin{array}{c}0.4730 \pm \\
0.0396 \\
\end{array}$ & $\begin{array}{c}0.0710 \pm \\
0.0042 \\
\end{array}$ & $\begin{array}{c}0.1115 \pm \\
0.0101 \\
\end{array}$ & - & $\begin{array}{c}0.0750 \pm \\
0.017\end{array}$ & 0.172 \\
\hline Nov & 60 & $\begin{array}{c}0.3980 \pm \\
0.0552 \\
\end{array}$ & $\begin{array}{c}0.1385 \pm \\
0.0035\end{array}$ & $\begin{array}{c}0.0615 \pm \\
0.0092 \\
\end{array}$ & $\begin{array}{c}0.3200 \pm \\
0.0424\end{array}$ & $\begin{array}{c}0.1635 \pm \\
0.0431 \\
\end{array}$ & $\begin{array}{c}0.1365 \pm \\
0.0262\end{array}$ & - & $\begin{array}{c}0.0190 \pm \\
0.0042\end{array}$ & 0.176 \\
\hline Dec & 20 & $\begin{array}{c}0.2195 \pm \\
0.0361 \\
\end{array}$ & $\begin{array}{c}0.0255 \pm \\
0.0035 \\
\end{array}$ & $\begin{array}{c}0.0360 \pm \\
0.0212 \\
\end{array}$ & $\begin{array}{c}0.2055 \pm \\
0.0304 \\
\end{array}$ & $\begin{array}{c}0.1050 \pm \\
0.0184 \\
\end{array}$ & $\begin{array}{c}0.1635 \pm \\
0.0233 \\
\end{array}$ & - & $\begin{array}{c}0.0080 \pm \\
0.0014 \\
\end{array}$ & 0.109 \\
\hline Jan & 5 & $\begin{array}{c}0.2955 \pm \\
0.0884\end{array}$ & $\begin{array}{c}0.0730 \pm \\
0.0269\end{array}$ & $\begin{array}{c}0.0365 \pm \\
0.0205 \\
\end{array}$ & $\begin{array}{c}0.2520 \pm \\
0.0410 \\
\end{array}$ & $\begin{array}{c}0.0685 \pm \\
0.0021\end{array}$ & $\begin{array}{c}0.0845 \pm \\
0.0290 \\
\end{array}$ & $\begin{array}{c}0.0100 \pm \\
0.6099 \\
\end{array}$ & $\begin{array}{c}0.0050 \pm \\
0.0014\end{array}$ & 0.103 \\
\hline Feb & 50 & $\begin{array}{c}0.1515 \pm \\
0.0149 \\
\end{array}$ & - & $\begin{array}{c}0.0375 \pm \\
0.0092 \\
\end{array}$ & $\begin{array}{c}0.1650 \pm \\
0.0071 \\
\end{array}$ & $\begin{array}{c}0.0640 \pm \\
0.0113 \\
\end{array}$ & $\begin{array}{c}0.0610 \pm \\
0.0028 \\
\end{array}$ & $\begin{array}{c}0.0300 \pm \\
0.0057 \\
\end{array}$ & - & 0.073 \\
\hline Mar & 100 & $\begin{array}{c}0.1370 \pm \\
0.0948\end{array}$ & $\begin{array}{c}0.0250 \pm \\
0.028\end{array}$ & $\begin{array}{c}0.0215 \pm \\
0.0050\end{array}$ & $\begin{array}{c}0.1705 \pm \\
0.0050\end{array}$ & - & $\begin{array}{c}0.0875 \pm \\
0.0474 \\
\end{array}$ & $\begin{array}{c}0.0375 \pm \\
0.0149 \\
\end{array}$ & - & 0.080 \\
\hline
\end{tabular}

Absorbance in absorbance units $(\mathrm{AU}) ; \mathrm{R}=+0.31$

$\mathrm{P}>0.05 ; \quad \mathrm{df}=11 *$ measured in $\mathrm{mm}$ 
Table 2:

The monthly mean absorbance values of TB samples

\begin{tabular}{|c|c|c|c|c|c|c|c|c|c|c|}
\hline Month & TB 01 & TB 02 & ТВ03 & TB04 & TВ 05 & ТВ 06 & ТВ 07 & ТВ 08 & MEAN & $\begin{array}{c}(\mathrm{t}) \\
\text { VALUE }\end{array}$ \\
\hline April 1 & $\begin{array}{c}0.0540 \pm \\
0.0156\end{array}$ & $\begin{array}{c}0.0625 \pm \\
0.0078\end{array}$ & $\begin{array}{c}0.1460 \pm \\
0.0396\end{array}$ & $\begin{array}{c}0.0455 \pm \\
0.0191\end{array}$ & $\begin{array}{c}0.1460 \pm \\
0.0792\end{array}$ & $\begin{array}{c}0.0630 \pm \\
0.0170\end{array}$ & $\begin{array}{c}0.0365 \pm \\
0.0035\end{array}$ & $\begin{array}{c}0.0400 \pm \\
0.0255\end{array}$ & 0.074 & 2.620 \\
\hline May & - & $\begin{array}{c}0.0345 \pm \\
0.0007 \\
\end{array}$ & $\begin{array}{c}0.0395 \pm \\
0.0205 \\
\end{array}$ & - & $\begin{array}{c}0.212 \pm \\
0.024 \\
\end{array}$ & $\begin{array}{c}0.0320 \pm \\
0.0156 \\
\end{array}$ & - & $\begin{array}{c}0.0050 \pm \\
0.0028 \\
\end{array}$ & 0.065 & 0.013 \\
\hline June & $\begin{array}{c}0.0370 \pm \\
0.001\end{array}$ & $\begin{array}{c}0.0280 \pm \\
0.0071 \\
\end{array}$ & $\begin{array}{c}0.0970 \pm \\
0.0028 \\
\end{array}$ & $\begin{array}{c}0.0275 \pm \\
0.0134 \\
\end{array}$ & $\begin{array}{c}0.1530 \pm \\
0.0693 \\
\end{array}$ & $\begin{array}{c}0.1715 \pm \\
0.0007\end{array}$ & - & - & 0.085 & 0.902 \\
\hline July & - & $\begin{array}{c}0.0325 \pm \\
0.0078\end{array}$ & $\begin{array}{c}0.1135 \pm \\
0.0431\end{array}$ & $\begin{array}{c}0.0315 \pm \\
0.0106\end{array}$ & $\begin{array}{c}0.1680 \pm \\
0.0297\end{array}$ & $\begin{array}{c}0.0635 \pm \\
0.0007\end{array}$ & $\begin{array}{c}0.0150 \pm \\
0.0028\end{array}$ & $\begin{array}{c}0.1020 \pm \\
0.0240\end{array}$ & 0.075 & 0.253 \\
\hline Aug & $\begin{array}{c}0.0335 \pm \\
0.0064 \\
\end{array}$ & $\begin{array}{c}0.0595 \pm \\
0.0163 \\
\end{array}$ & $\begin{array}{c}0.0590 \pm \\
0.0113 \\
\end{array}$ & $\begin{array}{c}0.0310 \pm \\
0.0226 \\
\end{array}$ & $\begin{array}{c}0.2645 \pm \\
0.0686 \\
\end{array}$ & $\begin{array}{c}0.0680 \pm \\
0.0368\end{array}$ & $\begin{array}{c}0.0110 \pm \\
0.0014\end{array}$ & $\begin{array}{c}0.0950 \pm \\
0.0325 \\
\end{array}$ & 0.078 & 0.276 \\
\hline Sep & $\begin{array}{c}0.0230 \pm \\
0.0042 \\
\end{array}$ & $\begin{array}{c}0.0540 \pm \\
0.0071 \\
\end{array}$ & $\begin{array}{c}0.1140 \pm \\
0.0240 \\
\end{array}$ & $\begin{array}{c}0.0190 \pm \\
0.0057 \\
\end{array}$ & $\begin{array}{c}0.2020 \pm \\
0.0014 \\
\end{array}$ & $\begin{array}{c}0.1630 \pm \\
0.0354 \\
\end{array}$ & $\begin{array}{c}0.0150 \pm \\
0.0042 \\
\end{array}$ & $\begin{array}{c}0.0985 \pm \\
0.0745 \\
\end{array}$ & 0.084 & 0.240 \\
\hline Oct & $\begin{array}{c}0.0335 \pm \\
0.012\end{array}$ & - & $\begin{array}{c}0.0710 \pm \\
0.002\end{array}$ & $\begin{array}{c}0.0060 \pm \\
0.0042\end{array}$ & $\begin{array}{c}0.1175 \pm \\
0.0050\end{array}$ & $\begin{array}{c}0.1665 \pm \\
0.0488\end{array}$ & $\begin{array}{c}0.080 \pm \\
0.0071\end{array}$ & $\begin{array}{c}0.1210 \pm \\
0.0085\end{array}$ & 0.065 & 1.512 \\
\hline Nov & $\begin{array}{c}0.1490 \pm \\
0.0212 \\
\end{array}$ & $\begin{array}{c}0.0810 \pm \\
0.0113 \\
\end{array}$ & $\begin{array}{c}0.1050 \pm \\
0.0014 \\
\end{array}$ & $\begin{array}{c}0.0165 \pm \\
0.0007 \\
\end{array}$ & $\begin{array}{c}0.2330 \pm \\
0.0297 \\
\end{array}$ & - & $\begin{array}{c}0.1380 \pm \\
0.0679 \\
\end{array}$ & $\begin{array}{c}0.1320 \pm \\
0.024 \\
\end{array}$ & 0.122 & 0.253 \\
\hline Dec & $\begin{array}{c}0.0270 \pm \\
0.0155 \\
\end{array}$ & $\begin{array}{c}0.0490 \pm \\
0.0014 \\
\end{array}$ & $\begin{array}{c}0.1320 \pm \\
0.0014 \\
\end{array}$ & $\begin{array}{c}0.0170 \pm \\
0.0042 \\
\end{array}$ & $\begin{array}{c}0.1760 \pm \\
0.0042 \\
\end{array}$ & $\begin{array}{c}0.1415 \pm \\
0.0644 \\
\end{array}$ & $\begin{array}{c}0.0220 \pm \\
0.0028 \\
\end{array}$ & $\begin{array}{c}0.1175 \pm \\
0.0191 \\
\end{array}$ & 0.087 & 0.512 \\
\hline Jan & $\begin{array}{c}0.0570 \pm \\
0.0014\end{array}$ & $\begin{array}{c}0.0410 \pm \\
0.0099\end{array}$ & $\begin{array}{c}0.0730 \pm \\
0.0608\end{array}$ & $\begin{array}{c}0.0375 \pm \\
0.0064\end{array}$ & $\begin{array}{c}0.1930 \pm \\
0.0071\end{array}$ & $\begin{array}{c}0.0865 \pm \\
0.0078\end{array}$ & - & $\begin{array}{c}0.1880 \pm \\
0.0014\end{array}$ & 0.097 & 0.170 \\
\hline Feb & $\begin{array}{c}0.0790 \pm \\
0.0269 \\
\end{array}$ & $\begin{array}{c}0.0535 \pm \\
0.0134 \\
\end{array}$ & $\begin{array}{c}0.1725 \pm \\
0.0078 \\
\end{array}$ & $\begin{array}{c}0.0300 \pm \\
0.0042 \\
\end{array}$ & $\begin{array}{c}0.1415 \pm \\
0.1054 \\
\end{array}$ & $\begin{array}{c}0.1425 \pm \\
0.0084 \\
\end{array}$ & - & $\begin{array}{c}0.0840 \pm \\
0.0240 \\
\end{array}$ & 0.101 & 0.230 \\
\hline Mar & - & $\begin{array}{c}0.0290 \pm \\
0.0014 \\
\end{array}$ & $\begin{array}{c}0.1115 \pm \\
0.0177 \\
\end{array}$ & $\begin{array}{c}0.0870 \pm \\
0.0283 \\
\end{array}$ & $\begin{array}{c}0.2130 \pm \\
0.0028 \\
\end{array}$ & $\begin{array}{c}0.1585 \pm \\
0.0347 \\
\end{array}$ & - & - & 0.120 & 0.672 \\
\hline April 2 & $\begin{array}{c}0.0285 \pm \\
0.0035\end{array}$ & - & $\begin{array}{c}0.1685 \pm \\
0.0219\end{array}$ & $\begin{array}{c}0.0575 \pm \\
0.0191\end{array}$ & $\begin{array}{c}0.2550 \pm \\
0.0679\end{array}$ & $\begin{array}{c}0.1600 \pm \\
0.0948\end{array}$ & - & $\begin{array}{c}0.1855 \pm \\
0.0545\end{array}$ & 0.143 & 0.690 \\
\hline
\end{tabular}

' $\mathrm{t}$ ' t test (*significantly different) between mean of FA and TB absorbance values)

April $_{12}=1^{\text {st }}$ and following year $(1991 \& 1992) ; \mathrm{R}=-0.32 ; \mathrm{df}=11$

Table 2: The monthly mean absorbance values of TB samples

Table 3: Summary of result and cases of malaria recorded. (Confirmed fromclinic health records)

The month of may recorded the minimum antibody titre for both FA and TB samples $(0.045 \pm 0.006 \mathrm{AU}$ and $0.065 \pm 0.083 \mathrm{AU}$ respectively). A statistical comparison using the one-tailed student's t-test showed no significant difference between these two values $(\mathrm{t}=0.0133$; $\mathrm{P}>0.05$; $\mathrm{df}=6)$. The mean absorbances showed a significant difference only in the month of April, 1992 ( $\mathrm{t}=2.62 ; \mathrm{P}>0.05$; $\mathrm{df}=11)($ table 1$)$.

The pearson correlation coefficient analysis of the mean absorbance of FA with TB samples showed a negative correlation $(\mathrm{r}=-0.0041 ; \mathrm{P}>0.05 ; \mathrm{df}=11)$.

Correlation of Rainfall distribution with mean absorbencies: The amount of rainfall peaked in the month of June with the least being recorded in January (Figs 1 \& 2 ). There was a positive correlation between mean absorbance and rainfall distribution for the various months for FA samples $(\mathrm{r}=+0.31 ; \mathrm{P}>0.05, \mathrm{df}=11)$ while that for TB samples showed a negative correlation ( $\mathrm{r}=$ 0.3.2); $\mathrm{P}>0.05 ; \mathrm{df}=11$ ). (Tables $1 \& 2$ ).

\section{DISCUSSION AND CONCLUSION}

A considerably high number of the subjects produced antibodies that were reactive with the circumsporozoite recombinant peptide, R32tet32 (7 from each village amounting to 14 out of $16-87.5 \%$ from both villages). The level of antibody response was not dependent on the number of clinical malaria infection .

This remark is consistent with the stage and species specificity of the immune response. Thus, the $\mathrm{Ab}$ response profile measured could serve as a useful indicator of the level of malaria transmission. Druihle et al (1986) and Esposito et al (1988) equally corroborated this 
conclusion.

Table 3:

Summary of result and cases of malaria recorded. (Confirmed from clinic health records).

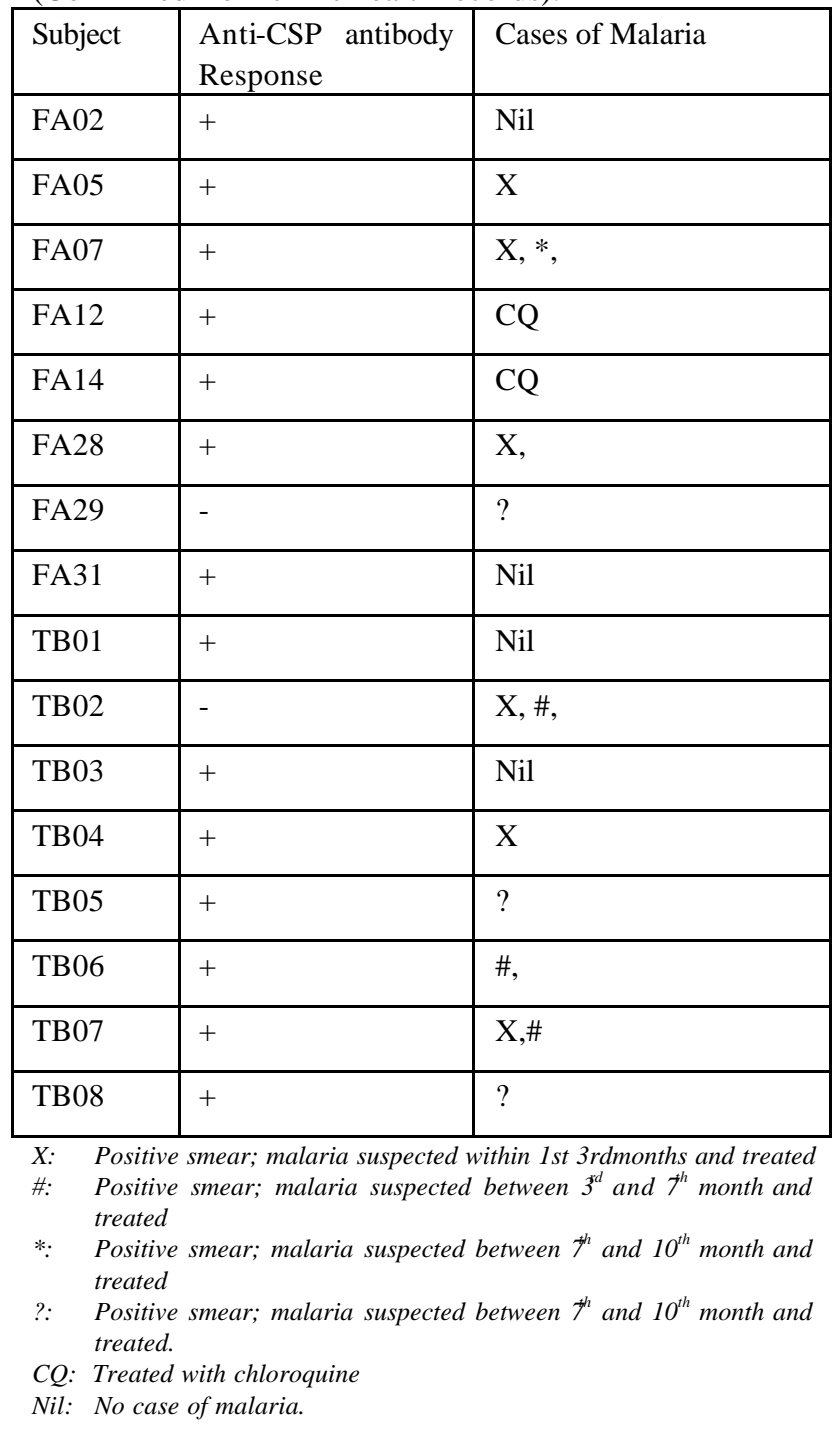

Except for F29 and TB02 (Tables $1 \& 2$ respectively) who both responded negatively, all other subjects that recorded cases of malaria were responders (Table 3) This illustrates the fact that, it is possible that rising antibody levels was experienced in subjects at the time a blood stage infection that was sufficient to cause symptoms developed (Webster et al, 1987). Also, it conforms with the discovery that inoculation of sporozoites which results in acute $P$. falciparum infection may or may not stimulate an antibody response to sporozoite antigens (Brown et al, 1989).

TB08, TB05, TB06, TB07, FA05, FA07, FA14, and FA28 all recorded peaks after the first case of suspected malaria was treated and suggests that the first episode of malaria may have been only partially treated while the second case was probably just a recrudescence. Occasionally, after treatment, there were instances in which $\mathrm{Ab}$ titres failed to show a significant rise during subsequent episodes (FA31, TB01, TB04 and TB07). There were also instances in which the periods of positive $\mathrm{Ab}$ response failed to correspond with the periods in which subjects were treated such as in FA29 and TB02 which were non-responders throughout.

The inconsistent nature of some of these highlighted results, relating $\mathrm{Ab}$ responses and recorded cases of malaria (Tables $1,2 \& 3$ ) could be as result of variation in T-cell epitope(s) to which the helper T-lymphocyte were responding (Good et al, 1988), especially when there is an antigen defect in the T-helper lymphocyte function while the general levels of $\mathrm{Ab}$ responses recorded could have been influenced by the half-life of immunoglobulin $\mathrm{G}(\mathrm{IgG})$ antibodies (Young et al, 1985), and the blood stage specificity of the circumsporozoite proteins (Dame et al, 1984).

However, some subjects still showed consistencies in which periods of positive anti-circumsporozoite protein responses corresponded with the periods in which malaria cases were recorded - FA02, FA12, FA14,FA28, TB05, TB06 and TB08 (Tables 1,2 \& 3 ). Responders FA02, FA31, TB01 TB03 that showed no case of malaria during the period of survey also showed consistencies in results.

Despite the location of the two villages within the same geographical zone with similar socio-economic settings, varying seasonal profiles of $\mathrm{Ab}$ response was recorded. High levels of $\mathrm{Ab}$ response was recorded between April and October for FA (rainy season period) while it was between November and April for TB (dry season period).

Furthermore, the antibody response profile for FA samples showed a positive correlation with rainfall $(\mathrm{r}=+0.31 ; \mathrm{P}>0.05)$ while that of TB samples was negatively correlated $(\mathrm{r}=-0.32 ; \mathrm{P}>0.05)$ (Table $1 \& 2)$. The trend in FA is similar to that obtained by Webster et al (1988) in South Western Thailand. This they attributed to a combination of factors involving human and vector (mosquito) behaviour which determine their exposure to infection. Examination of these micro variations may reveal other clues useful for control. Nwagwu et al (1998) reported seasonal relationship from the outcome of their study in which they dealt more on the immune status of the subjects, in the adjoining border villages within the same community. Knowledge of variation in parasite populations, if any, according to dry/low season in a place is of particular interest in Africa and other endemic areas for national malaria control programme. (Issifou et al, 2001). Studies on the relief of the two villages showed that they both have streems that dry up from November to 
march and which both fill up in the rainy season (Daly MT, Filani MO and Richards P, unpublished report). This implies that positive titres (responses) and indeed episodes of malaria are expected to fall sharply between November and March, the period in which most of the collected water must have drained up, as this was the case in only Afefu village. This not withstanding, both villages still showed significantly high levels of positive titres and it could be attributed to the rocky nature of both areas which provide suitable breeding sites for mosquitoes in the villages.

Since parasite, vectorial, environmental, climatic and human (such as habits and immunity status) factors, are some of the major parameters which greatly influence the epidemiology and level of disease transmission (Snow et al., 1988; Craig et. al., 1999), it is not unlikely that the varying response profiles for Afefu and Tobalogbo could be related to the habits and the climate, of which rainfall (brought into focus in this work), temperature, humidity and topography are the most important in malaria epidemiology (Ukoli, 1990). They affect the life cycle and behaviour of the mosquito vector and the rate of the development of the parasite within it. Amongst these factors, only rainfall and temperature are used as the basis for establishing models to predict risk of malaria transmission. These sort of models have been shown to provide a good estimation of malaria spatial risk (WHO/TDR, 2004; MARA/ARMA, 2001). It is worth noting that the habits of the subjects in both villages involve daily and seasonal variation in their exposure to the risks of infection. The earlier highlighted epidemiological factors are known to determine man's clothing, housing and general life style and it would definitely ripple out on the degree of exposure and level of transmission of the disease. Snow et al., (1998) supports this assertion as they reported that climate operates to affect the vectorial capacity of $P$. falciparum transmission with rainfall acting by limiting transmission potential, while survival, abundance and infectious periods of malaria vectors rely upon suitable climatic conditions (Lindsay and Birley, 1996). With the launching of Nigeria sat-1 by the National Space Research and Development Agency (NASRDA) of Nigeria in September, 2003, its potential for detailed climatic data supplies can be exploited in epidemiological surveys involving malaria and other infections diseases. This should alongside, data obtained from parasitological and georeferencing work, help in spatial modeling of malaria distribution patterns and establish sub-populations at risk (MARA/ARMA, 2001; WHO/TDR, 2004). This approach has proved particularly useful in countries like China where only one province (Yunnan) remains with a significant transmission level of Plasmodium falciparum (TDR News 70, 2003).

What then is the role of the ELISA employed in malaria epidemiology one might ask? The answer is simple. Despite its possible sources of human and technical error Wirtz et. al. (1998), which is of minimal significance, it still serves as a useful indicator of sporozoite parasite inoculation, thereby shedding more light on the natural history of host-parasite relationship and in seroepidemiological surveys, whose use in control programmes has shown promise, irrespective of the odds.

These corroborative findings (despite the sample size) suggests firmer approach to the management of human (habits) and environmental factors by those living in endemic areas, such as in the areas under study, especially when these factors are more controllable than the innate features. Coupling these to malaria risk mapping would greatly support planning and implementation of our control programmes. Future expanded sample-size studies is advocated for further insight, as this presented data will serve as a baseline.

\section{ACKNOWLEDGEMENT}

- $\quad$ This work was party financed and supported by the Research Strengthening Group of the UNDP/World Bank/WHO Special Programme for Research and Training in Tropical Diseases through a grant awarded to Professor M. Nwagwu (Rtd).

- We appreciate the kind cooperation of the two villages in Igbo-Ora community and members of the programme's field team.

- We thank Dr. R. A. Wirtz of Walter Reed Army Institute of Medical Research, Washington D.C., USA, for his gift of the recombinant capture antigen - R32tet32 used for the ELISA.

- Huge thanks also to medical and non-medical personnel of the College of Medicine, University of Ibadan, attached to the Igbo-Ora Community Health programme for technical assistance and use of their facilities.

\section{REFERENCES}

Babiker H.A., Abdel - Mushin A.M., Ranford - Cartwright L.C., Satti G., Walliker D. (1998). Characteristics of Plasmodium falciparum parasites that survive the lengthy dry season in Eastern Sudan where malaria transmission is markedly seasonal., Am J Trop Med and Hyg 59 (4): 582-90.

Brown A.E., Webster H.K., Pavanand K., Barnyen P., Sookto J.S. and Gingrich J.B. (1989). Comparison of antibody responses to the circumsporozoite protein repeat region and to intact sporozoites during acute falciparum malaria. Trans R Soc Trop Med and Hyg; 154-157.

Cochrane A.H., Nussenzweig R.S. and Nardin E.H. (1980). Immunization against sporozoites. J.P Kreier ed. New York Academy Press, Malaria; 3:163-202.

Craig M.H, Snow R.W. and Le Sueur D.A. (1999). Climatebased distribution model of malaria transmission in Africa. Parasitology Today; 15: 105-111.

Dame J.B., Williams J..L., McCutchan T.F., Weber J.L., Wirtz R.A., Hockmeyer W.R., Maloy W.L., Haynes J.D., Scheneider I., Roberts D., Sanders G.S., Reddy E.P., Diggs C.L. and Miller L.H. (1984) Structure of the gene encoding the immunodominant surface antigen on the sporozoite of the human 
malaria parasite, Plasmodium falciparum. Science; 225: 593 599.

Druilhe P., Pradier P.O., Marc J.P., Miltgen F., Mazier D. and Parent G. (1986) .Levels of antibodies to plasmodium falciparum sporozoite surface antigens reflect malaria transmission rates and are present in the absence of reinfection. Infect Immune; 53:393-397.

Durrheim D.N., Govere J., La Grange J.J.P., Mabuza A. (2001) Rapid immunochromatographic diagnosis and Rolling Back malaria-experiences from an African control programme. Afr J Med Sci; 30,Suppl. 21-24.

Esposito F., Lombardi S., Modiano D., Zavala F., Reeme J., Lamizana L., Coluzzi M. and Nussenzweig R.S. (1988). Prevalence and levels of antibodies to the circumsprozoite protein of Plasmodium falciparum in an endemic area and their relationship to resistance against malaria infection. Trans $\mathrm{R}$ Soc Trop Med and Hyg; 82:827-832.

Good M.F., Berzofsky J.A. and Miller L.H. (1988). The T-cell response to malaria circumsporozoite protein and immunological approach to vaccine development. Ann Rev Immunol.; 6: 663688.

Issifou S., Ndjikou S., Sanni A., Lekoulou F., Ntoumi F. (2001). No influence of the transmission season on genetic diversity and complexity of infections in Plasmodium falciparum isolates from Benin, Afr J Med Sci; 30, suppl.17-20. Lindsay SW and Birley MH. Climate change and malaria transmission. (1997) Annals of Tropical Medicine and Parasitology; 90:573-588.

MARA/ARMA. (1998). Towards on Atlas of malaria Risk in Africa. First Technical Report of the MARA/ARMA Collaboration 1998, Durban.

Nussenzweig V. and Nussenzweig R.S. (1985). Circumsporozoite proteins of malaria parasites. Cell; 42: 401403

Nwagwu M., Anumudu C.A., Sodeinde O., Ologunde C.A., Obi T.U, Wirtz R.A., Gordon D.M. and Lyon J.A. (1998). Identification of a subpopulation of immune Nigerian Adult Volunteers by antibodies to the circumsporozoite protein of Plasmodium falciparum. Am J Trop Med Hyg; 58(5): 684-692. Snow R.W., Gows E., Omumbo J., Rapuoda B., Craig M.H., Transer F.C., Le Sueur D. and Ouma J. (1998). Model to predict the intensity of Plasmodium falciparum transmission: applications to the burden of the disease in Kenya. Trans R Sec
Trop Med Hyg; 92: 601-606.

Tapchaisri P.A., Asavanich S., Limsuwan S., Tharavanji S. and Harinasuta T. (1985). Antibodies against malaria sporozoites in patients with acute uncomplicated malaria and patients with cerebral malaria. Am J Trop Med Hyg; 34:831836.

Tapchaisri P.A., Chomcharm C.P. Asavanich A., Limsuman S., Maleevan O., Tharvanj S. and Harinasuta T. (1983). Anti-sporozoite antibodies indusced by natural infection. Am J Trop Med Hyg; 32: 1203-1208.

TDR News. (1983) A UNDP/World Bank/WHO Publication ; 70 , Oct: 15 .

TDR (1993) Report of the Steering Committee of the Scientific Working Group on Epidemiology. July 1978 - June 1983; Document TDR/EPI/SC-SWG (78-83)/83.3.

Ukoli F.M.A. (1990). Introduction to Parasitology in Tropical Africa ; Textflow Ltd. Ibadan.

Van der Hoek W , Konradsen F., Dijkstra D.S., Amerisinghe P.H., Amerasinghe F.P. (1998). Risk factors for malaria: a microepidemiological study in a village in Sri Lanka. Trans R Soc Trop Med Hyg; 92 (3): 265-9.

Webster H.K., Boudreau E.F., Pang L.W., Permpanich B., Sookto P. and Wirtz R.A. (1987). Development of Immunity in Natural Plasmodium falciparum Malaria: Antibodies to the falciparum sporozoite vaccine / antigen (R32tet32). J. Cli Microbiol.; .25. (6): 1002-1008.

Webster H.K., Brown A.E., Chuenchitra C., Permpanich B. and Pipithkul J. (1988) .Characterization of antibodies to sporozoites in plasmodium falciparum malaria and correction with protection. J Cli Microbial; 2: 923-927.

WHO/TDR (2004) Predicting Malaria Epidemics in Africa. 1997-98 Malaria / AFR-Progress report.

Wirtz R.A., Duncan J.F., Njelesani E.K., Schneider I., Brown A.E., Oster C.N., Were J.B., Webster H.K. (1989). ELISA method for detecting Plasmodium falciparum circumsporozoite antibody. Bull World Health Organ; 67: 535542.

Young J.F., Hockmeye W.T., Gross M., Ballou W.P., Wirtz R.A., Trosper J.H., Beaudoin R.L., Hollingdale M.R., Miller LH, Diggs C.L. and Rosenberg M. (1985). Expression of Plasmodium falciparum circumsporozoite proteins in E.coli for potential use in a malaria vaccine. Science; 288: 958-962. 